\title{
Characterization of perlites from Jastrabá and Lehôtka pod Brehmi deposits
}

\author{
Peter Varga ${ }^{1}$, Jaroslav Lexa ${ }^{2}$, Peter Uhlík ${ }^{1}$, Michal Rajnoha ${ }^{1}$ \\ ${ }^{1}$ Comenius University, Faculty of Natural Sciences, Department of Economic Geology; Mlynská dolina G, \\ 84215 Bratislava, Slovakia; e-mail:vargap@nic.fns.uniba.sk \\ ${ }^{2}$ Slovak Academy of Science, Geological Institute; Dúbravská cesta 9, 84005 Bratislava, Slovakia
}

(C) 2015 Authors. This is an open access publication, which can be used, distributed and reproduced in any medium according to the Creative Commons CC-BY 4.0 License requiring that the original work has been properly cited.

Perlite is an important industrial mineral with unique properties. It is an acid volcanic glass (rhyolitic or rhyodacitic) with a water content between 1 to $5 \%$. The largest industrial use is in the form of expanded pearlite. This produced by rapidly heated, grinded natural perlite at $600-900^{\circ} \mathrm{C}$ (Barker \& Santini 2006). Perlite occurrences represent economic accumulation in Slovakia. Perlite is mined at the Lehôtka pod Brehmi deposit for a long time and now is starting to open Jastrabá deposit. The aim of this paper is characterization and correlation of samples of both deposits and samples from locality Szabova skala due to their different genesis. The perlite from Lehôtka pod Brehmi deposit has been characterized by X-ray powder diffraction, IR spectroscopy and thermal analysis in the current research (Uhlík et al. 2014). Any significant differences were not identified in the content of volcanic glass, crystalline phases, or content of water. Only one differences have been observed in the macroscopically different perlite glasses (color, texture) - porosity. The macroscopically (color, texture) of different perlite glasses differences were once in porosity. The purpose of this article is to characterize the perlite sample by optical microscopy, X-ray powder diffraction and microprobe analysis. The characterization of perlitic glass is important not only for the mining company because of heterogeneity of Lehôtka pod Brehmi deposit, but also from a scientific point of view and about 30-years gap of perlite studies in the Central
Slovakian Volcanic Field (Capková 1976, Kraus et al. 1980, 1985, Zuberec et al. 1980, 1983).

The authors thank to the Slovak Research and Development Agency for the support of the project APVV-0339-12.

\section{REFERENCES}

Barker J. \& Santini K., 2006. Perlite. [in:] Kogel J., Trivedi N., Barker J. \& Krukowski S. (eds), Industrial Minerals and Rocks (7th ed.), Society for Mining, Metallurgy and Exploration, Denver, Colorado, 685-702.

Capková A., 1975. Mineralogicko-petrografické štúdium perlitov $v$ stredoslovenských neovulkanitoch. DP, KLG Prif UK.

Kraus I., Šamajová E., Gerthofferová H. \& Lajčáková A., 1980. Minerálne zloženie a genéza ílových surovín, zeolitov a perlitov. Záverečná správa. Geologický ústav PF UK, Bratislava.

Kraus I., Šamajová E., Gerthofferová H. \& Lajčáková A., 1985. Genéza, distribúcia a prognózy nerúd vo vulkanitoch a neogéne Západných Karpát. Záverečná správa. Geologický ústav PF UK, Bratislava.

Uhlík P., Lexa J., Pálková H., Madejová J., Blištan P. \& Bizovská V., 2014. Basic characterization of perlite from Lehôtka pod Brehmi deposit and its surrounds (Slovakia). 7th Mid-European Clay Conference, 16-19 September 2014, Dresden, Germany.

Zuberec J., Hroncová Z., Sýkora J. \& Valko P., 1980. Lehôtka pod Brehmi, Jastrabá - stredoslovenské neovulkanity, surovina: perlit. Záverečná správa a výpočet zásob. SGÚ Bratislava, GP Spišská Nová Ves.

Zuberec J., 1983. Geologicko-ložiskové pomery ílových surovín, perlitov a limnokvarcitov Kremnických a Štiavnických hôr. PriF UK Bratislava [PhD thesis]. 